\title{
Adaptation to osmotic stress provides protection against ammonium nitrate in Pelophylax perezi embryos
}

\author{
Manuel E. Ortiz-Santaliestra ${ }^{\mathrm{a}, *}$, María José Fernández-Benéitez ${ }^{\mathrm{a}}$, Miguel Lizana ${ }^{\mathrm{a}}$, Adolfo Marco ${ }^{\mathrm{b}}$ \\ ${ }^{a}$ Department of Animal Biology, University of Salamanca, Campus Miguel de Unamuno, 37007 Salamanca, Spain \\ b Doñana Biological Station, Spanish Council for Scientific Research, C/Americo Vespucio s/n, 41092 Sevilla, Spain \\ Natural resistance to salinity minimizes the impact of chemical fertilizers on amphibian embryos.
}

\section{a b s t r a c t}

Keywords: Amphibian

decline Intraspecific

variation Local

adaptation Multiple

stressors

Salinity

\begin{abstract}
The negative effects of pollution on amphibians are especially high when animals are additionally stressed by other environmental factors such as water salinity. However, the stress provoked by salinity may vary among populations because of adaptation processes. We tested the combined effect of a common fertilizer, ammonium nitrate $\left(0-90.3 \mathrm{mg} \mathrm{N}-\mathrm{NO}_{3} \mathrm{NH}_{4} / \mathrm{L}\right)$, and water salinity (0-2\&) on embryos of two Pelophylax perezi populations from ponds with different salinity concentrations. Embryos exposed to the fertilizer were up to $17 \%$ smaller than controls. Survival rates of embryos exposed to a single stressor were always below $10 \%$. The exposure to both stressors concurrently increased mortality rate $(>95 \%)$ of embryos from freshwater. Since the fertilizer was lethal only when individuals were stressed by the salinity, it did not cause lethal effects on embryos naturally adapted to saline environments. Our results underscore the importance of testing multiple stressors when analyzing amphibian sensitivity to environmental pollution.
\end{abstract}

\section{Introduction}

Because of the permeability of their skin, amphibians are very sensitive to osmotic stress; therefore, water salinity constitutes a critical factor in habitat suitability and survival probabilities of these animals (Beebee, 1985). Salinity levels above concentrations typical of freshwaters $(0-0.5 \&)$ may produce diverse physiological malfunctions, such as an alteration of respiratory function (Mahajan et al., 1979) or abnormalities in the circulatory system (Parsons et al., 1990). Nevertheless, some amphibian populations are quite capable of living in brackish waters (0.5-32\& salinity) and, exceptionally, in saline waters (32-37.5\&). Some coastal populations of Bufo calamita in Sweden breed in waters with a $4 \&$ salinity (Andrén and Nilson, 1985), while other populations of this species can breed close to the Baltic Sea, in water bodies with a $28 \&$ salinity (Gislen and Kauri, 1959). Uchiyama et al. (1990) found individuals of Fejervarya cancrivora, the amphibian with the highest salinity tolerance found so far, in ponds with the same salt concentration as that of seawater

* Corresponding author. Present address: Department of Wildlife Ecology, University of Wisconsin, 1630 Linden Drive, Madison, WI 53706, USA. Tel.: p1 608 692 2599; fax: p1 6082629922.

E-mail addresses: ortizsantali@wisc.edu (M.E. Ortiz-Santaliestra), may_beneitez@yahoo.es (M.J. Fernández-Benéitez), lizana@usal.es (M. Lizana), amarco@ebd. csic.es (A. Marco).
(33\&). However, these amphibians that appear in brackish or saline waters are specific populations that are exceptionally tolerant of moderate or even high salinity levels, while other populations of these same species are unable to live in osmotically stressful environments (Gomez-Mestre and Tejedo, 2003). There are no known cases of an amphibian species whose populations are all adapted to osmotic stress.

Water pollution is another factor that may affect different populations of the same amphibian species in a distinct way. For example, Johansson et al. (2001) found that Rana temporaria tadpoles from an area with a high nitrate load, as a consequence of the use of fertilizers, were more resistant to the chemical than were tadpoles from a nitrate-free area. The fluctuations in environmental levels of many pollutants in the water might act as selection pressures for the organisms inhabiting these waters (Holloway et al., 1990). Therefore, the tolerance of certain amphibian populations to some agricultural chemicals to which they are usually exposed could be the consequence of genetic adaptation. For example, Egea-Serrano et al. (2009) suggested that a local adaptation to nitrogen contamination had happened among Pelophylax perezi populations inhabiting areas exposed to agricultural pollution over the last three decades. However, while the existence of genetic adaptation has been demonstrated for some of the observed salinity-resistant populations (e.g., Gomez-Mestre and Tejedo, 2003), there is as yet no evidence, to our knowledge, of 

genetic adaptation of amphibians to environmental pollution. As suggested by some authors, the pace of the environmental change in the case of pollutants would be too rapid to allow the genetic adaptation of animals to chemical stress (Bürger and Lynch, 1997). Consequently, geographic variations in sensitivity to pollutants would therefore be due to environmentally induced sources such as phenotypic variation (Falfushinska et al., 2008) or maternal effects (Räsänen and Kruuk, 2007).

While intraspecific differences in amphibian sensitivity to a specific stressor have been occasionally elucidated, little is known about how different populations of the same species respond to the combined effects of various factors. Because previous research has demonstrated that the presence of two or more factors can cause sublethal chemical stressors to become lethal when conditions are altered (Hatch and Blaustein, 2003; Relyea, 2003), examining the roles of multiple stressors is essential if we are to understand how to protect community processes. Testing chemicals individually can underestimate the risk posed to wildlife (Sih et al., 2004). A number of papers published during the last decade emphasize that combinations of stressors may be enhancing the negative effects of each stressor alone, often having interactive effects not predicted from single-factor studies (e.g., Blaustein et al., 2003; Boone and James, 2003; Boone et al., 2005, 2007; Johnson et al., 2006; Relyea and Mills, 2001). With regards to nitrogenous compounds, deleterious consequences have been noted in response to their combination with other environmental factors such as pesticides (Boone et al., 2005), UV-B radiation (Hatch and Blaustein, 2000, 2003; Macías et al., 2007), or low $\mathrm{pH}$ (Hatch and Blaustein, 2000). In addition, Egea-Serrano et al. (2009) demonstrated that the exposure of amphibian larvae to combinations of different nitrogenous compounds affected larval survival and food consumption more severely than did exposure to single compounds.

The combined effects of nitrogen pollution and high salinity levels could be especially relevant in water bodies impacted by agricultural activities. Chemical fertilizers applied to crop fields constitute by far the main source of inorganic nitrogen pollution in freshwater ecosystems (Vitousek et al., 1997). In addition, agricultural activities indirectly increase water salinity, because of the substitution of natural perennial vegetation by crops of herbaceous plants with small root systems that do not penetrate deeply into the soil (Hart et al., 2003). Shallow rooting may reduce the soil retention of nutrients and minerals, which are then easily transported by runoff to the nearby water bodies. Loman and Lardner (2006) found, in Southern Sweden, that ponds located in agricultural lands showed higher conductivity and nitrogenous compound concentrations than did ponds outside the agricultural areas.

We hypothesize that the combined exposure to a common fertilizer, ammonium nitrate, and increased water salinity may have synergistic toxic effects on amphibian embryos, and that these effects may vary as a function of the local adaptation to any of these stressors. Previous research has demonstrated that embryos are generally not as sensitive as young larvae when exposed to chemical stress (Meredith and Whiteman, 2008; Ortiz-Santaliestra et al., 2006), which is commonly attributed to the protective role of the gelatinous envelope (Edginton et al., 2007; Marquis et al., 2006). However, the embryonic jelly coat is permeable to some toxic chemicals such as the pyrethroid insecticide a-cypermethrin (Greulich and Pflugmacher, 2003).

Inorganic nitrogen, including ammonium nitrate, may inhibit the eclosion (Ortiz-Santaliestra et al., 2007) or decrease embryonic growth and development, which ultimately reduces survival probabilities during the larval stage (Griffis-Kyle, 2005). Increased levels of nitrate $\left(25 \mathrm{mg} \mathrm{N}-\mathrm{NO}_{3}^{-} / \mathrm{L}\right)$ and nitrite $\left(>3.5 \mathrm{mg} \mathrm{N}-\mathrm{NO}_{2}^{-} / \mathrm{L}\right)$ inhibit hatching success and cause mortalities in hatched amphibian larvae of several amphibian species (Marco et al., 1999).
Ponds with higher levels of nitrate have been reported to have lower densities of egg masses and poorer hatching success for three amphibian species (Laposata and Dunson, 2000). An increased level of ammonia (up to $1.27 \mathrm{mg} / \mathrm{L}$ ) caused a decrease in egg hatch in Rana aurora and Ambystoma gracile (De Solla et al., 2002). Concentrations over $0.6 \mathrm{mg} / \mathrm{L}$ of unionized ammonia decreased survival, increased the prevalence of abnormalities and slowed growth and development in Lithobates clamitans embryos. Similar effects were reported for Lithobates pipiens embryos with concentrations in excess of $1.5 \mathrm{mg} \mathrm{NH} / \mathrm{L}$ (Jofre and Karasov, 1999).

Regarding the impact of salinity on amphibian aquatic stages, contrary to what happens with inorganic nitrogen, embryos would be, in most of cases, more sensitive than are larvae to osmotic stress, especially during the gastrulation and neurulation stages (Viertel, 1999). A review of the available literature indicates that embryos of non-adapted amphibian populations can tolerate moderate salinity concentrations. For example, Viertel (1999) estimated a 'no observed effect concentration' (NOEC) of 2.2\& salinity for embryonic R. temporaria. Similarly, Microhyla ornata embryos were not affected by a $2 \&$ salinity concentration (Padhye and Ghate, 1992), while survival rates over $50 \%$ were observed in Rhinella marina at 3.5\& salinity (Ely, 1944), in R. temporaria at 3.7\& (Viertel, 1999), and in B. calamita at $4 \&$ salinity concentration (Beebee, 1985). On the other hand, higher concentrations may impair embryonic survival. For example, Beebee (1985) reported 100\% mortality in B. calamita embryos in waters with a salinity concentration of $7 \&$.

The aim of the present study was to analyze the intraspecific differences in the embryonic sensitivity of two Iberian green frog (P. perezi) populations to a combined exposure to ammonium nitrate and osmotic conditions corresponding to fresh or brackish waters. For this purpose, we used embryos from two localities with similar nitrogen load and different salinity levels.

P. perezi occurs throughout the Iberian Peninsula, where it is one of the most abundant amphibians, and also can be found in southern France. It occupies almost all kinds of water bodies in all types of habitats and is known to tolerate brackish water (Kadel and Hemmer, 1980) and moderate concentrations of water pollution, as deduced from its presence in highly eutrophic agricultural habitats (Llorente et al., 2002). In the region where we collected the eggs for the present study, embryonic development lasts for an average of 8-12 days, depending essentially on the temperature (Diego-Rasilla and Ortiz-Santaliestra, 2009). The duration of larval development is highly variable and depends on the environmental conditions, with metamorphs usually emerging between 8 and 12 weeks after laying. Recent research has revealed that larval survival is affected by exposure to environmentally relevant levels of ammonium, but not by nitrate or nitrite (Egea-Serrano et al., 2009). We are unaware of the existence of experimental data that quantify the resistance of P. perezi to osmotically stressful environments.

\section{Materials and methods}

We collected P. perezi eggs from two locations in West Central Spain in April 2005. The eggs from the first population (ZA) were collected in the Lagunas de Villafáfila Natural Reserve, in Zamora province $\left(41^{\circ} 50^{\circ} 08^{00} \mathrm{~N}, 5^{\circ} 35^{\circ} 24^{00} \mathrm{~W}\right)$. The eggs from the other population (SA) were collected in the Prado de la Hermida lake, in Salamanca province $\left(41^{\circ} 05^{0} 36^{\infty} \mathrm{N}, 5^{\circ} 36^{0} 48^{00} \mathrm{~W}\right)$. Both places have similar climatic conditions and are located in agricultural regions dominated by cereal crops. We selected these places because we had previous data on their salinity and nitrogen concentrations. According to those previous measurements, we expected differences between localities in terms of salinity but not in inorganic nitrogen concentrations. At the moment of egg collection, we measured water salinity (conductivity-meter Hanna HI 9835; Hanna Instruments ${ }^{\circledR}$, Eibar, Spain), pH (pHmeter Hanna HI 8314; Hanna Instruments ${ }^{\circledR}$, Eibar, Spain), dissolved oxygen (oximeter Handylab OXI/Set; Schott-Geräte ${ }^{\circledR}$, Hofheim, Germany), total hardness (test Visocolor ECO 931029; Macherey-Nagel ${ }^{\circledR}$, Düren, Germany), and nitrate, nitrite, and total ammonia concentrations (tests Visocolor ECO 931041, 931044 and 931 008, respectively; Macherey-Nagel ${ }^{\circledR}$, Düren, Germany). The obtained 
measurements are shown in Table 1 . As expected, salinity levels were substantially different between localities. While levels at SA were within the normal range for freshwater systems $(0-0.5 \&)$, waters from ZA could be considered as moderately brackish. Therefore, our comparison was of individuals from two populations with a different history in their environmental osmotic conditions.

Eggs at Gosner stages 10-11 ( $<24$ h; Gosner, 1960) from five different clutches were collected from both locations on the same day. The eggs were carried to the laboratory immediately after collection, where they were incubated at an air temperature of $18{ }^{\circ} \mathrm{C}$ and with a natural photoperiod. We used 54 containers with $300 \mathrm{~mL}$ of tap water filtered with activated carbon to remove chlorine and ammonia. Concentrations of nitrate, nitrite and total ammonia after filtering were below detection limits. Conductivity of the filtered water was $5.5 \mathrm{~ms} / \mathrm{cm}$. Each containe was assigned to a population, a nominal ammonium nitrate level $(0,22.6$, $90.3 \mathrm{mg} \mathrm{N}-\mathrm{NO}_{3} \mathrm{NH}_{4} / \mathrm{L}$ ) and an initial salinity level $(0 \&, 0.4 \&, 2 \&)$ in such way that each combination of treatments was replicated three times in a block design. The two experimental salinity levels were similar to those measured at the original ponds (see Table 1). The lowest ammonium nitrate level was selected from the nitrate legal maximum allowed for drinking waters (European Council, 1998); the highest fertilizer level was consistent with that expected in the amphibian breeding ponds located in agricultural environments just after the drainage of fertilizers by rains (Ortiz-Santaliestra et al., 2006; Scholefield et al., 1996). We did not consider the concentrations of nitrate, nitrite or ammonia measured at the ponds where eggs were collected because they were too low to be considered as potentially stressful. Moreover, some analyses made in these ponds during the amphibian reproductive season in subsequent years showed maximum levels above $100 \mathrm{mg} \mathrm{N}-\mathrm{NO}_{3}^{-} / \mathrm{L}$ and $10 \mathrm{mg} \mathrm{N}-\mathrm{NH}_{4}^{\mathrm{b}} / \mathrm{L}$ (unpublished data). To obtain the experimental levels, we added commercial sodium chloride and/or ammonium nitrate salt with $99 \%$ purity (Merck ${ }^{\circledR}$, Darmstaad, Germany) to the water. Water in all containers was changed every 6 days in a typical static-renewal design (Stephen, 1975); during that period, ammonium nitrate levels were not readjusted, so we expected a decrease in concentration of nitrate and ammonium over time, as happens in the field after fertilizer runoff (Bogardi et al., 1991). Inside each container we placed 20 eggs from the corresponding population (four eggs from each of the five clutches). The jelly coat of the eggs was left intact in order to retain the natural conditions of the egg environment as much as possible. The experiment began the day after egg collection, when embryos were at Gosner stage 12, and lasted for 12 days. We chose this 12-day period from the available data on embryonic development duration of the tested populations. All of the surviving embryos hatched between days 10 and 11 of the experiment, but none of them was yet able to swim when the experiment ended.

We recorded hourly temperatures during the experiment with a data-logger Hobo Water Temp Pro v2 (Onset Computer ${ }^{\circledR}$, Bourne, MA, USA) submerged in an additional container with the same characteristics as those used in the experiment. Water $\mathrm{pH}$ and conductivity were checked every 4 days, and concentrations of nitrate and total ammonia were measured at days 6 and 12 . All levels were readjusted at day 6 , after water renewal.

Mortality rates in each container were calculated every 3 days. To analyze the effects of population, salinity and ammonium nitrate, as well as their interactions, on embryonic survival, we used a three-way repeated measures analysis of variance with the increase of mortality rates (arcsine of square root transformed) over time as the dependent variable. At the end of the experiment, we recorded the total length (mouth to tail tip) of survivals with a digital caliper ACHA 17-264 (d 1/4 $0.01 \mathrm{~mm}$; $\mathrm{ACHA}^{\circledR}$, Eibar, Spain). We did a logarithmic transformation of larval lengths and analyzed them with a three-way analysis of variance (ANOVA). When the full threeway factorial models provided significant results, we conducted ANOVAs for each factor or combination of factors that produced significant effects, and the p-values were adjusted with a Bonferroni correction for multiple testing. Statistical analyses were run with the software SPSS 11.5 for Windows (SPSS Inc. ${ }^{\circledR}$, Chicago, IL, USA).

\section{Results}

No mortality occurred in controls. Both ammonium nitrate and salinity, as well as their interaction, significantly increased overall

Table 1

Water parameters measured in the ponds of origin of the embryos at the moment of collection.

\begin{tabular}{lll}
\hline Parameter & SA population & ZA population \\
\hline Conductivity $(\mathrm{ms} / \mathrm{cm})$ & 626 & 3180 \\
Salinity (\&) & 0.40 & 2.04 \\
$\mathrm{pH}$ & 7.40 & 7.42 \\
Dissolved oxygen $(\mathrm{mg} / \mathrm{L})$ & 12.43 & 13.91 \\
Total hardness $(\mathrm{mg} \mathrm{CaCO} / \mathrm{L})$ & 250.6 & 250.6 \\
Nitrate $(\mathrm{mg} \mathrm{N} / \mathrm{L})$ & 2 & 1 \\
Nitrite $(\mathrm{mg} \mathrm{N} / \mathrm{L})$ & 0.01 & $\mathrm{BDL}^{\mathrm{a}}$ \\
Total ammonium $(\mathrm{mg} \mathrm{N} / \mathrm{L})$ & 0.15 & 0.6 \\
\hline
\end{tabular}

${ }^{\mathrm{a}}$ BDL: below detection limits. embryonic mortality over time. In addition, sensitivity to both stressors, either alone or in combination, was different between populations (Table 2). Embryonic survival in the ZA population was not affected by any of the stressors (over $90 \%$ in all treatments), while a significant increase in lethality was observed for SA embryos exposed to either fertilizer or salinity. In this population, mortality was significantly higher only at the highest ammonium nitrate and salinity levels when compared to controls; at $90.3 \mathrm{mg} \mathrm{N}-\mathrm{NO}_{3} \mathrm{NH}_{4} / \mathrm{L}$, the overall embryonic mortality was $24 \%$, while less than $2 \%$ of the individuals exposed to $22.6 \mathrm{mg} \mathrm{N}-$ $\mathrm{NO}_{3} \mathrm{NH}_{4} / \mathrm{L}$ died. With regards to salinity, the overall mortality of SA embryos was $32 \%$ at the higher level and $12 \%$ at the lower one. Nevertheless, this significant lethality suffered by SA embryos was exclusively provoked by the synergistic effect of the two stressors; while the mortality rates caused by a single stressor were always lower than 2\% (Bonferroni test: $p>0.05$ ), the increase of salinity augmented the lethality caused by ammonium nitrate in such way that more than $95 \%$ of embryos exposed simultaneously to $90.3 \mathrm{mg} \mathrm{N}-\mathrm{NO}_{3} \mathrm{NH}_{4} / \mathrm{L}$ and $2 \&$ salinity had died by the end of the experiment (Fig. 1).

The total length of survivors did not vary significantly between populations, with mean values of $7.71 \mathrm{~mm}$ in SA, and $7.49 \mathrm{~mm}$ in ZA. According to the full three-way factorial model, both ammonium nitrate and salinity affected the length of hatchlings, although we did not detect any statistical interaction of the population of origin with the effects of any of the stressors or their interaction (Table 3). Ammonium nitrate reduced the growth rate of embryos in both populations. Hatchlings from the SA population were on average $8-16 \%$ smaller than controls, depending on the fertilizer level, while ZA individuals exposed to the highest ammonium nitrate level showed a total length that was $17 \%$ lower than that of the controls. However, in the case of salinity, the Bonferroni adjustment for multiple testing did not reveal any significant effect of this specific stressor on length in any of the populations (Fig. 2).

Mean water temperature was $17.2{ }^{\circ} \mathrm{C}$, with an average daily variation of $2.2{ }^{\circ} \mathrm{C}$. Mean water $\mathrm{pH}$ was 7.27 (range 7.18-7.41). Neither the ammonium nitrate concentration nor the salinity level affected water $\mathrm{pH}(\mathrm{p}>0.05)$. Mean salinity levels per treatment, calculated as the average values between the initial salinity concentrations and those measured before water change (day 6) and at the end of the experiment (day 12), were slightly higher than the initial values $(0.22 \&, 0.57 \&$ and $2.48 \&)$. The concentration of ammonium nitrate did not affect significantly water salinity $\left(F_{2,15} 1 / 4 \quad 0.211 ; p 1 / 40.812\right)$. Average fertilizer concentrations per treatment were $0,17.6$ and $76.6 \mathrm{mg} \mathrm{N}-\mathrm{NO}_{3} \mathrm{NH}_{4} / \mathrm{L}$; water salinity did not affect these concentrations $\left(F_{2,15} 1 / 40.001 ; p^{1 / 4} 0.999\right)$.

\section{Discussion}

We observed a clear intraspecific difference in the sensitivity of P. perezi embryos to ammonium nitrate and osmotic stress. The individuals from the ZA population, native to a more saline area, were more tolerant than were those of the SA population. This was evident not only for moderate salinity levels but also for fertilizer exposure. The ammonium nitrate concentration that did not affect individuals from the ZA population under the high salinity treatment was highly lethal to SA embryos.

In the $P$. perezi population from non-saline waters (SA), increased salinity levels acted as a stress source. The embryos of this population appear to be very sensitive in comparison with other cases of salinity-exposed amphibian embryos. For salinity concentrations close to our highest treatment (around 2\&), no lethal effects were detected in M. ornata (Padhye and Ghate, 1992) or R. temporaria (Viertel, 1999) embryos. Survival rates over 50\% were also found in embryos of other species exposed to salinity 
Table 2

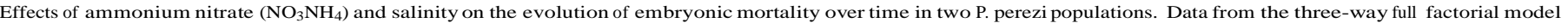
comparing both populations, as well as those from the separate two-ways analyses for each population are shown.

\begin{tabular}{|c|c|c|c|c|c|c|}
\hline & Source of variation & Sum of squares & df & Mean squares & $\mathrm{F}$ & $\mathrm{p}$ \\
\hline \multirow[t]{9}{*}{ Full model } & Time & 0.725 & 1 & 0.725 & 70.717 & $<0.000001$ \\
\hline & Time $\times$ population & 0.240 & 1 & 0.240 & 23.412 & 0.000025 \\
\hline & Time $\times$ salinity & 0.295 & 2 & 0.147 & 14.372 & 0.000026 \\
\hline & Time $\times \mathrm{NO}_{3} \mathrm{NH}_{4}$ & 0.826 & 2 & 0.413 & 40.281 & $<0.000001$ \\
\hline & Time $\times$ population $\times$ salinity & 0.156 & 2 & 0.078 & 7.615 & 0.001746 \\
\hline & Time $\times$ population $\times \mathrm{NO}_{3} \mathrm{NH}_{4}$ & 0.379 & 2 & 0.190 & 18.502 & 0.000003 \\
\hline & Time $\times$ salinity $\times \mathrm{NO}_{3} \mathrm{NH}_{4}$ & 0.522 & 4 & 0.131 & 12.740 & 0.000001 \\
\hline & Time $\times$ population $\times$ salinity $\times \mathrm{NO}_{3} \mathrm{NH}_{4}$ & 0.419 & 4 & 0.105 & 10.213 & 0.000012 \\
\hline & Error & 0.369 & 36 & 0.010 & & \\
\hline \multirow[t]{5}{*}{ ZA population } & Time & 0.065 & 1 & 0.065 & 8.637 & 0.008776 \\
\hline & Time $\times$ salinity & 0.024 & 2 & 0.012 & 1.579 & 0.233503 \\
\hline & Time $\times \mathrm{NO}_{3} \mathrm{NH}_{4}$ & 0.043 & 2 & 0.022 & 2.845 & 0.084433 \\
\hline & Time $\times$ salinity $\times \mathrm{NO}_{3} \mathrm{NH}_{4}$ & 0.049 & 4 & 0.012 & 1.614 & 0.214095 \\
\hline & Error & 0.136 & 18 & 0.008 & & \\
\hline \multirow[t]{5}{*}{ SA population } & Time & 0.899 & 1 & 0.899 & 69.543 & $<0.000001$ \\
\hline & Time $\times$ salinity & 0.427 & 2 & 0.213 & 16.500 & 0.000085 \\
\hline & Time $\times \mathrm{NO}_{3} \mathrm{NH}_{4}$ & 1.162 & 2 & 0.581 & 44.921 & $<0.000001$ \\
\hline & Time $\times$ salinity $\times \mathrm{NO}_{3} \mathrm{NH}_{4}$ & 0.892 & 4 & 0.223 & 17.246 & 0.000006 \\
\hline & Error & 0.233 & 18 & 0.013 & & \\
\hline
\end{tabular}

concentrations up to $4 \&$ (Beebee, 1985; Ely, 1944). Other studies have reported a high embryonic sensitivity of certain amphibian species exposed to 250-945 mg chloride/L (approximately 0.4-1.5\& salinity, Karraker and Ruthig, 2009; Turtle, 2000); however, these studies analyzed the effects of road de-icing salt which, in addition to sodium chloride, contains other chemicals such as sodium ferrocyanide (Paschka et al., 1999) or different heavy metals (Oberts, 1986) that may have had separate toxicity.

Apart from these effects on embryos, amphibians exposed to osmotic stress may show reduced larval growth and metamorphosis rates, and increased larval and adult mortality. For example, Sanzo and Hecnar (2006) calculated a 96 h median lethal concentration of $2.6 \&$ salinity in Lithobates sylvaticus. Christy and Dickman (2002) observed that sublethal salinity levels reduced the developmental rate of Litoria aurea tadpoles. This reduction of growth or developmental rate enhances the negative effect of salinity by delaying metamorphosis and thus prolonging larval exposure to the stressor.

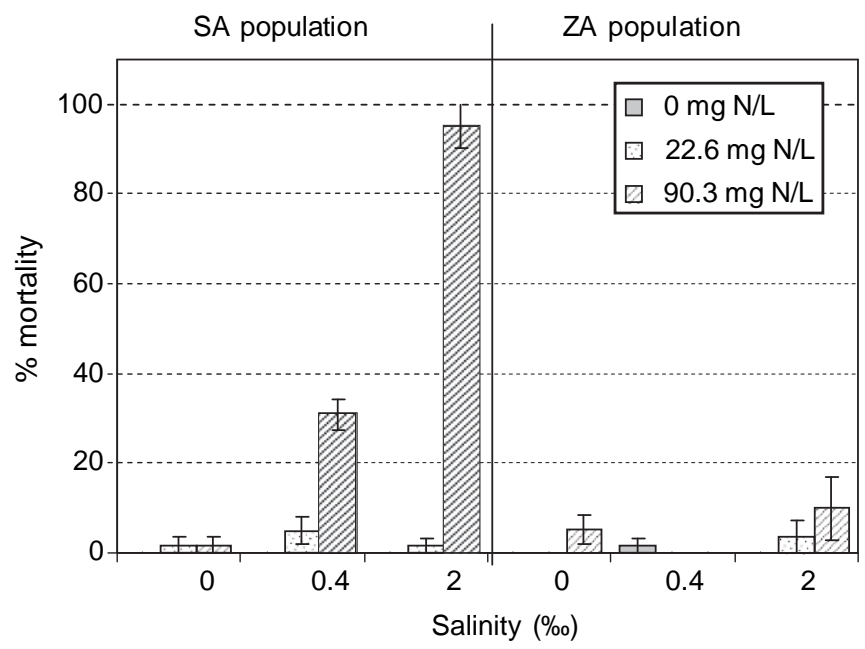

Fig. 1. Mortality rates $( \pm \mathrm{SE})$ per treatment of P. perezi embryos from two populations after 12 days of exposure to different ammonium nitrate and salinity levels.
In contrast to these deleterious effects of increased salinity on amphibians, the adaptation of some populations to brackish or even saline environments has also been reported. For example, GomezMestre and Tejedo (2003) demonstrated that the B. calamita populations from Southern Spain native to brackish water had a higher salinity tolerance than did freshwater populations, suggesting local adaptation. Furthermore, individuals from brackish waters that were transplanted to freshwater environments showed the same survival probabilities as did those native to freshwaters, indicating that an increased tolerance to osmotic stress does not imply a loss of performance in freshwater. However, Turtle (2000) also conducted transplant experiments with Ambystoma maculatum from roadside pools with high salinity levels and from woodland pools with low salinity concentrations. This author found that embryos from roadside pools had higher survival rates when transferred to woodland pools, possibly indicating that they were not adapted to the conditions of their native pool. Nevertheless, Turtle (2000) studied vernal pools affected by highway runoff, and additional stressors other than salinity could be acting on individuals growing in these pools. These transplant experiments conducted both by Gomez-Mestre and Tejedo (2003) and Turtle (2000) are useful for resolving the question of whether the resistance to salinity of some populations lies in a genetic adaptation or is simply because of a phenotypic acclimation with no evolutionary implications. B. calamita populations studied by GomezMestre and Tejedo (2003), native from a naturally brackish environment, would be genetically adapted and therefore its resistance to salinity would be an adaptive, inheritable character. On the other hand, the A. maculatum populations analyzed by Turtle (2000) inhabiting roadside pools would be able to resist high salinity concentrations as a consequence of an environmentally induced phenotypic acclimation, and no genetic adaption to brackish or saline environments would exist in these populations. Considering that ZA embryos showed the same survival rates regardless of whether salinity concentration was similar to that of their native habitat or lower, we could conclude that resistance to salinity in this population would be the consequence of a genetic adaptation.

With regards to the effects of ammonium nitrate, the concentrations used in the present study, in absence of any salinity effect, caused only a reduction in embryonic growth rate. Negative effects of environmentally relevant concentrations of ammonium nitrate on growth rates of amphibian aquatic stages have been reported in 
Table 3

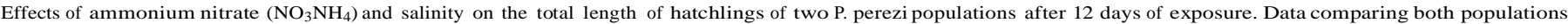
and those from each population separately are shown.

\begin{tabular}{|c|c|c|c|c|c|}
\hline Source of variation & Sum of squares & df & Mean squares & $\mathrm{F}$ & $\mathrm{p}$ \\
\hline Population & 0.001 & 1 & 0.001 & 0.715 & 0.403672 \\
\hline Salinity & 0.009 & 2 & 0.004 & 4.629 & 0.016674 \\
\hline $\mathrm{NO}_{3} \mathrm{NH}_{4}$ & 0.052 & 2 & 0.026 & 28.070 & $<0.000001$ \\
\hline Population $x$ salinity & 0.002 & 2 & 0.001 & 0.827 & 0.445855 \\
\hline Population $\times \mathrm{NO}_{3} \mathrm{NH}_{4}$ & 0.000 & 2 & 0.000 & 0.152 & 0.859232 \\
\hline Salinity $\times \mathrm{NO}_{3} \mathrm{NH}_{4}$ & 0.006 & 4 & 0.002 & 1.723 & 0.167657 \\
\hline Population $\times$ salinity $\times \mathrm{NO}_{3} \mathrm{NH}_{4}$ & 0.002 & 4 & 0.001 & 0.603 & 0.663044 \\
\hline Error & 0.032 & 34 & 0.001 & & \\
\hline
\end{tabular}

a number of previous studies (Ortiz et al., 2004; Ortiz-Santaliestra et al., 2006; Schuytema and Nebeker, 1999; Watt and Oldham, 1995; $\mathrm{Xu}$ and Oldham, 1997). The disadvantages of a reduced size in amphibian aquatic stages are well known. Individuals that reach metamorphosis with a smaller size have lower survival probabilities during the juvenile period than do larger metamorphs (Berven, 1990; Semlitsch et al., 1988; Smith, 1987). Nevertheless, our experiment was not prolonged during the larval stage and thus we cannot confirm that the observed reduction in growth rate during the embryonic period would have been reflected in a lower size at metamorphosis.

A review of the available literature on the effects of ammonium nitrate on amphibians affirms the consideration of $\mathrm{P}$. perezi as a tolerant species. In previous experiments, we have detected lethal effects of the same ammonium nitrate levels as those used in this experiment on embryos and larvae of Hyla arborea, Bufo bufo and Discoglossus galganoi (Ortiz et al., 2004). The mortality rate of Pseudacris regilla embryos after 10 days of exposure to $101.8 \mathrm{mg} \mathrm{N}$ $\mathrm{NO}_{3} \mathrm{NH}_{4} / \mathrm{L}$ was $80 \%$, and the mortality rate of Xenopus laevis embryos after 5 days of exposure to the same concentration was 53.5\% (Schuytema and Nebeker, 1999). As in P. perezi, embryos of other species have been found to be more resistant to ammonium nitrate. For example, identical levels to what were used in the present study did not reduced survival of Pelobates cultripes or Triturus pygmaeus embryos (Ortiz-Santaliestra et al., 2006, 2007).

There are some cases where amphibian populations are known to tolerate moderate levels of contamination (e.g., Semlitsch et al., 2000). With regards to nitrate, Johansson et al. (2001) reported that R. temporaria individuals from a population naturally exposed to a high nitrate load were less sensitive to the negative effects of this

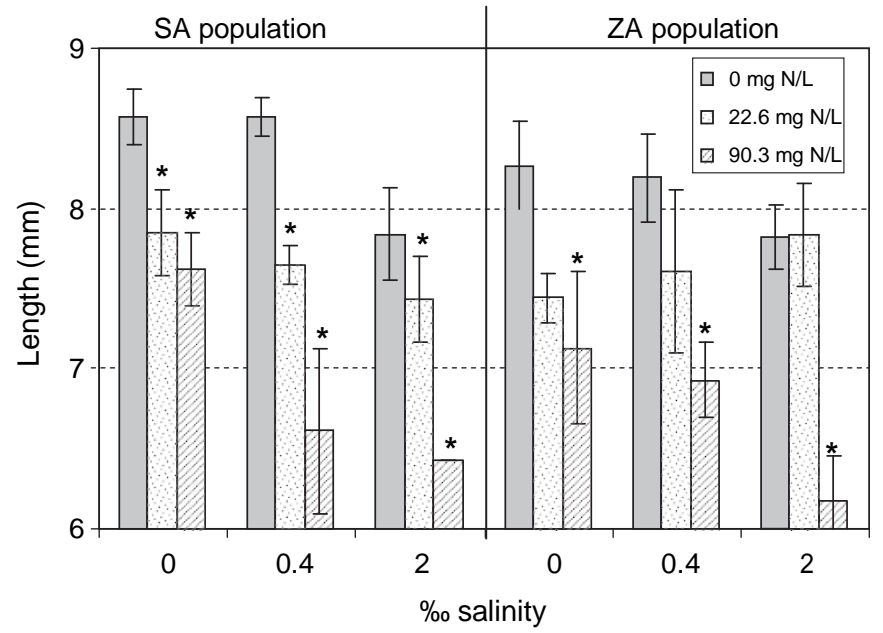

Fig. 2. Larval length per treatment in two P. perezi populations after 12 days of exposure to different ammonium nitrate and salinity levels. Asterisks indicate the treatments that were significantly different from the controls $(\mathrm{p}<0.05)$ according to the Bonferroni tests for multiple comparison adjustment. chemical than were the individuals from a non-exposed population. Egea-Serrano et al. (2009) also found that P. perezi tadpoles from a nitrogen polluted area showed lower mortality rates when exposed in the laboratory to high concentrations of ammonium, either alone or in combination with nitrate and nitrite. These authors suggested that populations breeding in habitats exposed to high levels of toxicant nitrogenous compounds may have evolved rapidly in response to environmental nitrification in a pronounced process of selection. Bridges and Semlitsch (2000), who observed differences in sensitivity to the pesticide carbaryl among Lithobates sphenocephala populations, also suggested a process of local adaptation to the chemical to explain the reported differences. These hypothetical phenomena of rapid local adaptation to anthropogenic pollution seem compatible with the idea that environmental stress, especially stress of contemporary anthropogenic origin, is a strong force generating local adaptations and rapid evolution (Carroll et al., 2007; Hoffmann and Hercus, 2000). However, contrary to what happens with salinity in those populations that historically inhabit brackish environments, it is not clear whether the population-dependent tolerance to anthropogenic contamination reported by Johansson et al. (2001), EgeaSerrano et al. (2009) or Bridges and Semlitsch (2000) is actually because of a genetic adaptation, and further research would be needed to clarify this question. Nonetheless, in the present study we did not detect differences between populations in sensitivity to ammonium nitrate alone, as we would expect from the fact that the levels of nitrogenous compounds were similar in both ponds.

In spite of the absence of differences between populations in sensitivity to ammonium nitrate alone, we found a high toxicity in SA embryos when the fertilizer was combined with high salinity levels, while no similar effects were observed in ZA individuals. Since lethality is not caused by a single factor, but is a consequence of synergistic effects between the two stressors, the natural adaptation of ZA individuals to salinity possibly prevents these animals from suffering any ill effects of the ammonium nitrate at the levels tested. Analyzing the combined effect of nitrite and ambient UV radiation, Macías et al. (2007) found a synergism of different magnitude in two P. perezi populations, but did not describe any phenomenon of adaptation to any stressor that could have reduced the overall effect of the combination.

Some of the mechanisms related to the exposure to nitrogenous fertilizers or osmotically stressful environments may contribute to the explanation of why the population adapted to salinity was also more tolerant to ammonium nitrate toxicity. Gosner and Black (1957) confirmed that high salinity levels prevented water diffusion into the egg because of the alteration of osmotic equilibrium; therefore, the volume of the space inside the egg did not increase and embryos suffered malformations as they were growing. An excess of ammonium or nitrate in the water could have the same effect on water exchange throughout the egg envelope by altering the osmotic equilibrium. Embryos adapted to salt should have a mechanism to avoid the reduced uptake of water, and this strategy 
could be also beneficial when dealing with high levels of inorganic nitrogenous compounds. Wright et al. (2004) demonstrated that one of the physiological mechanisms involved in the high resistance of F. cancrivora to osmotically stressful environments is an active regulation of the urea-ornithine cycle. Under highly saline conditions, juvenile frogs increase the rate of urea synthesis to accumulate osmotically active metabolites thus equilibrating the osmotic potential inside and outside the organism and avoiding an excessive dehydration. Furthermore, urea synthesis and excretion is the main route of ammonia detoxification for amphibian aquatic stages (Schmuck et al., 1994). Therefore, we could expect that those species with a higher efficiency in the activation of the urea-ornithine cycle will be able not only to resist high salinity, but also to efficiently detoxify ammonia. However, urea-ornithine cycle happens in the liver, and since the liver in anuran amphibians does not develop until early larval stages (Duellman and Trueb, 1994), this hypothesis may not be appropriate to explain the observed effects on P. perezi embryos. In general, organ development in amphibian embryos is minimal, so the physiological mechanisms to avoid the negative effects of high salinity and/or inorganic nitrogen should be related to active transport of water and ions across the skin and egg membrane. Unfortunately, nothing is known about how these organisms respond to osmotic stress at the physiological level.

Finally, the mechanism involved in the tolerance to osmotic stress and inorganic nitrogen could be related to the characteristics of the gelatinous envelope. Water diffusion across the jelly coat depends not only on the osmotic conditions inside and outside the egg, but also on the thickness and structure of the envelope. The embryonic jelly coat is made of glycoproteins, mucopreoteins and carbohydrates (e.g., Freeman, 1968), and it has a high diffusion capacity for hydrophilic substances such as sodium, chlorine, nitrate or ammonium (Salthe, 1963). However the thickness and structure of the jelly coat, and therefore its permeability to these substances, may vary (Carroll et al., 1991; Seymour, 1995). Adaptation to osmotic stress could involve a gelatinous envelope that would be less permeable to the uptake of ions or to the loss of water, which indirectly would benefit the organisms when dealing with inorganic nitrogenous chemicals.

\section{Conclusions}

We have demonstrated that the genetic adaptation of P. perezi embryos to moderately saline environments helps them to cope with an excess of inorganic nitrogen in the water. As the lethality produced by these two factors is a consequence of their combined action, the fact that one of the factors does not act as a true stressor in one of the populations minimizes the overall risk for that population. To our knowledge, the case reported in the present study is the first in amphibians that demonstrates how the adaptation to a natural stressor may indirectly generate a resistance against the toxicity of a chemical. Our results emphasize the necessity of evaluating multiple stressors, arising from both natural factors and anthropogenic impacts, as the potential causes for currently observed declines in amphibian populations (Linder et al., 2003). In addition, the high intraspecific variability in the susceptibility to one or all of these stressors needs to be evaluated when planning conservation strategies at a local scale.

\section{Acknowledgments}

Gonzalo Alarcos helped with the design of the experiments. Funding was provided by the Regional Government of Castilla y León (SA071A06) and the Ministry of Science and Innovation of Spain (CGL2005-0372).

\section{References}

Andrén, C., Nilson, G., 1985. Habitat and other environmental characteristics of the natterjack toad (Bufo calamita Laur.) in Sweden. British Journal of Herpetology 6, 419-424.

Beebee, T.J.C., 1985. Salt tolerances of natterjack toad (Bufo calamita) eggs and larvae from coastal and inland populations in Britain. Herpetological Journal 1, 14-16.

Berven, K.A., 1990. Factors affecting population fluctuations in larval and adult stages of the wood frog (Rana sylvatica). Ecology 71, 1599-1608.

Blaustein, A.R., Romansic, J.M., Kiesecker, J.M., Hatch, A.C., 2003. Ultraviolet radiation, toxic chemicals and amphibian population declines. Diversity and Distributions $9,123-140$.

Bogardi, I., Kuzelka, R.D., Ennenga, W.G., 1991. Nitrate Contamination: Exposure, Consequence, and Control, NATO ASI Series G, vol. 30. Springer-Verlag, New York, NY.

Boone, M.D., Bridges, C.M., Fairchild, J.F., Little, E.E., 2005. Multiple sublethal chemicals negatively affect tadpoles of the green frog, Rana clamitans. Environmental Toxicology and Chemistry 24, 1267-1272.

Boone, M.D., James, S.M., 2003. Interactions of an insecticide, herbicide, and natural stressors in amphibian community mesocosms. Ecological Applications 13, 829-841.

Boone, M.D., Semlitsch, R.D., Little, E.E., Doyle, M.C., 2007. Multiple stressors in amphibian communities: effects of chemical contamination, bullfrogs and fish. Ecological Applications 17, 291-301.

Bridges, C.M., Semlitsch, R.D., 2000. Variation in pesticide tolerance of tadpoles among and within species of ranidae and patterns of amphibian decline. Conservation Biology 14, 1490-1499.

Bürger, R., Lynch, M., 1997. Adaptation and extinction in changing environments. EXS 83, 209-239.

Carroll Jr., E.J., Wei, S.H., Nagel, G.M., Ruibal, R., 1991. Structure and macromolecular composition of the egg and embryo jelly coats of the anuran Lepidobatrachus laevis. Development Growth and Differentiation 33, 37-43.

Carroll, S.P., Hendry, A.P., Reznick, D.N., Fox, C.W., 2007. Evolution on ecological time-scales. Functional Ecology 21, 387-393.

Christy, M.T., Dickman, C.R., 2002. Effects of salinity on tadpoles of the green and golden bell frog (Litoria aurea). Amphibia-Reptilia 23, 1-11.

De Solla, S.R., Pettit, K.E., Bishop, C.A., Cheng, K.M., Elliott, J.E., 2002. Effects of agricultural runoff on native amphibians in the lower Fraser River Valley, British

Columbia, Canada. Environmental Toxicology and Chemistry 21, 353-360. DiegoRasilla, F.J., Ortiz-Santaliestra, M.E., 2009. Naturaleza en Castilla y León. Los Anfibios. Caja de Burgos, Burgos.

Duellman, W.E., Trueb, L., 1994. Biology of Amphibians, second ed. John Hopkins University Press, Baltimore, MD.

Edginton, A.N., Rouleau, C., Stephenson, G.R., Boermans, H.J., 2007. 2,4-D butoxyethyl ester kinetics in embryos of Xenopus laevis: the role of the embryonic jelly coat in reducing chemical absorption. Archives of Environmental Contamination and Toxicology 52, 113-120.

Egea-Serrano, A., Tejedo, M., Torralva, M., 2009. Populational divergence in the impact of three nitrogenous compounds and their combination on larvae of the frog Pelophylax perezi (Seoane, 1885). Chemosphere 76, 869-877.

Ely, C.A., 1944. Development of Bufo marinus larvae in dilute seawater. Copeia 1944, 256.

European Council, 1998. Council Directive 98/83/EC of 3 November 1998 on the Quality of Water Intended for Human Consumption. In: Official Journal of the European Communities 05/12/98, L330/32-L330/54.

Falfushinska, H.I., Romanchuk, L.D., Stolyar, O.B., 2008. Different responses of biochemical markers in frogs (Rana ridibunda) from urban and rural wetlands to the effect of carbamate fungicide. Comparative Biochemistry and Physiology C $148,223-229$.

Freeman, S.B., 1968. A study of the jelly envelopes surrounding the egg of the amphibian, Xenopus laevis. Biological Bulletin 135, 501-513.

Gislen, T., Kauri, H., 1959. Zoogeography of the Swedish amphibians and reptiles, with notes on their growth and ecology. Acta Vertebratica 1, 197-397.

Gomez-Mestre, I., Tejedo, M., 2003. Local adaptation of an anuran amphibian to osmotically stressfuls environments. Evolution 57, 1889-1899.

Gosner, K.L., 1960. A simplified table for staging anuran embryos and larvae with notes on identification. Herpetologica 16, 183-190.

Gosner, K.L., Black, I.H., 1957. The effect of acidity on the development and hatching of New Jersey frogs. Ecology 38, 256-262.

Greulich, K., Pflugmacher, S., 2003. Differences in susceptibility of various life stages of amphibians to pesticide exposure. Aquatic Toxicology 65, 329-336.

Griffis-Kyle, K.L., 2005. Ontogenic delays in effects of nitrite exposure on tige salamanders (Ambystoma tigrinum tigrinum) and wood frogs (Rana sylvatica). Environmental Toxicology and Chemistry 24, 1523-1527.

Hart, B.T., Lake, P.S., Webb, J.A., Grace, M.R., 2003. Ecological risk to aquatic systems from salinity increases. Australian Journal of Botany 51, 689-702.

Hatch, A.C., Blaustein, A.R., 2000. Combined effects of UV-B, nitrate, and low pH reduce the survival and activity level of larval Cascades frogs (Rana cascadae). Archives of Environmental Contamination and Toxicology 39, 494-499.

Hatch, A.C., Blaustein, A.R., 2003. Combined effects of UV-B radiation and nitrate fertilizer on larval amphibians. Ecological Applications 13, 1083-1093.

Hoffmann, A.A., Hercus, M.J., 2000. Environmental stress as an evolutionary force Bioscience 50, 217-226.

Holloway, G.J., Sibly, R.M., Povey, S.R., 1990. Evolution in toxin-stressed environments. Functional Ecology 4, 289-294. 
Jofre, M.B., Karasov, W.H., 1999. Direct effect of ammonia on three species of North American anuran amphibians. Environmental Toxicology and Chemistry 18, 1806-1812.

Johansson, M., Räsänen, K., Merilä, J., 2001. Comparison of nitrate tolerance between different populations of the common frog, Rana temporaria. Aquatic Toxicology 54, 1-14.

Johnson, P.T.J., Preu, E.R., Sutherland, D.R., Romansic, J.M., Han, B., Blaustein, A.R., 2006. Adding infection to injury: synergistic effects of predation and parasitism on amphibian malformations. Ecology 87, 2227-2235.

Kadel, B., Hemmer, H., 1980. Studien am Wasserfrösch -Rana perezi (Seoane, 1885)der Balearen (Amphibia, Anura, Ranideae). Bolletí de la Societat d'Història Natural de les Balears 24, 55-70.

Karraker, N.E., Ruthig, G.R., 2009. Effect of road deicing salt on the susceptibility of amphibian embryos to infection by water molds. Environmental Research 109, 40-45.

Laposata, M.M., Dunson, W.A., 2000. Effects of spray-irrigated wastewater effluent on temporary pond-breeding amphibians. Ecotoxicology and Environmental Safety 46, 192-201.

Linder, G., Krest, S.K., Sparling, D.W., 2003. Amphibian Decline: an Integrated Analysis of Multiple Stressor Effects. SETAC, Pensacola, FL.

Llorente, G.A., Montori, A., Carretero, M.A., Santos, X., 2002. Rana perezi Seoane, 1885. Rana común. In: Pleguezuelos, J.M., Márquez, R., Lizana, M. (Eds.), Atlas y libro rojo de los anfibios y reptiles de España. Ministerio de Medio Ambiente y Asociación Herpetológica Española, Madrid, pp. 126-128.

Loman, J., Lardner, B., 2006. Does pond quality limit frogs Rana arvalis and Rana temporaria in agricultural landscapes? A field experiment. Journal of Applied Ecology 43, 690-700.

Macías, G., Marco, A., Blaustein, A.R., 2007. Combined exposure to ambient UVB radiation and nitrite negatively affects survival of amphibian early life stages. Science of the Total Environment 385, 55-65.

Mahajan, C.L., Sharma, S.D., Sharma, S.P., 1979. Tolerance of aquatic organisms to chloride salts. Indian Journal of Experimental Biology 17, 1244-1245.

Marco, A., Quilchano, C., Blaustein, A.R., 1999. Sensitivity to nitrate and nitrite in pond-breeding amphibians from the Pacific Northwest, USA. Environmental Toxicology and Chemistry 18, 2836-2839.

Marquis, O., Millery, A., Guittonneau, S., Miaud, C., 2006. Toxicity of PAHs and jelly protection of eggs in the common frog Rana temporaria. Amphibia-Reptilia 27, $472-475$.

Meredith, C.S., Whiteman, H.H., 2008. Effects of nitrate on embryos of three amphibian species. Bulletin of Environmental Contamination and Toxicology 80, 529-533.

Oberts, G.L., 1986. Pollutants associated with sand and salt applied to roads in Minnesota. Journal of the American Water Resources Association 22, 479-483.

Ortiz, M.E., Marco, A., Saiz, N., Lizana, M., 2004. Impact of ammonium nitrate on growth and survival of six European amphibians. Archives of Environmental Contamination and Toxicology 47, 234-239.

Ortiz-Santaliestra, M.E., Marco, A., Fernández, M.J., Lizana, M., 2006. Influence of developmental stage on sensitivity to ammonium nitrate of aquatic stages of amphibians. Environmental Toxicology and Chemistry 25, 105-111.

Ortiz-Santaliestra, M.E., Marco, A., Fernández-Benéitez, M.J., Lizana, M., 2007. Effects of ammonium nitrate exposure and water acidification on the dwarf newt: the protective effect of oviposition behaviour on embryonic survival. Aquatic Toxicology 85, 251-257.

Padhye, A.D., Ghate, H.V., 1992. Sodium chloride and potassium chloride tolerance of different stages of the frog, Microhyla ornata. Herpetological Journal 2, 18-23.

Parsons, R.H., Thorn, L.M., Salerno, S.M., Petronis, S., 1990. Salt-load effects on osmotic water flow, tritiated water diffusion, and cardiovascular system in Rana pipiens and Rana catesbeiana. Physiological Zoology 63, 571-586.
Paschka, M.G., Ghosh, R.S., Dzombak, D.A., 1999. Potential water-quality effects from iron cyanide anticaking agents in road salt. Water Environment Research 71, 1235-1239.

Räsänen, K., Kruuk, L.E.B., 2007. Maternal effects and evolution at ecological timescales. Functional Ecology 21, 408-421.

Relyea, R.A., 2003. Predator cues and pesticides: a double dose of danger for amphibians. Ecological Applications 13, 1515-1521.

Relyea, R.A., Mills, N., 2001. Predator-induced stress makes the pesticide carbaryl more deadly to gray treefrog tadpoles (Hyla versicolor). Proceedings of the National Academy of Sciences USA 98, 2491-2496.

Salthe, S.N., 1963. The egg capsules in the amphibian. Journal of Morphology 113, 161-171.

Sanzo, D., Hecnar, S.J., 2006. Effects of road de-icing salt ( $\mathrm{NaCl})$ on larval wood frogs (Rana sylvatica). Environmental Pollution 140, 247-256.

Schmuck, R., Geise, W., Linsenmair, K.E., 1994. Life cycle strategies and physiological adjustments of reedfrog tadpoles (Amphibia, Anura, Hyperoliidae) in relation to environmental conditions. Copeia 1994, 996-1007.

Scholefield, D., Lord, E.I., Rodda, H.J.E., Webb, B., 1996. Estimating peak nitrate concentrations from annual nitrate loads. Journal of Hydrology 186, 355-373.

Schuytema, G.S., Nebeker, A.V., 1999. Comparative effects of ammonium and nitrate compounds on Pacific treefrog and African clawed frog embryos. Archives of Environmental Contamination and Toxicology 36, 200-206.

Semlitsch, R.D., Bridges, C.M., Welch, A.M., 2000. Genetic variation and a fitness tradeoff in the tolerance of gray treefrog (Hyla versicolor) tadpoles to the insecticide carbaryl. Oecologia 125, 179-185.

Semlitsch, R.D., Scott, D.E., Pechmann, J.K., 1988. Time and size at metamorphosis related to adult fitness in Ambystomatalpoideum. Ecology 69, 184-192.

Seymour, R.S., 1995. Oxygen uptake by embryos in gelatinous egg masses of Rana sylvatica: the roles of diffusion and convection. Copeia 1995, 626-635.

Sih, A., Bell, A.M., Kerby, J.L., 2004. Two stressors are far deadlier than one. Trends in Ecology and Evolution 19, 274-276.

Smith, D.C., 1987. Adult recruitment in chorus frogs: effects of size and date at metamorphosis. Ecology 68, 344-350.

Stephen, C.E., 1975. Methods for Acute Toxicity Tests with Fish, Macroinvertebrates and Amphibians. EPA-660/3-75-009. US EPA, Corvallis, OR.

Turtle, S.L., 2000. Embryonic survivorship of the spotted salamander (Ambystoma maculatum) in roadside and woodland vernal pools in Southeastern New Hampshire. Journal of Herpetology 34, 60-67.

Uchiyama, M., Murakami, T., Yoshizawa, H., 1990. Notes on the development of the crab-eating frog, Rana cancrivora. Zoological Science 7, 73-78.

Viertel, B., 1999. Salt tolerance of Rana temporaria: spawning site selection and survival during embryonic development (Amphibia, Anura). Amphibia-Reptilia 20, 161-171.

Vitousek, P.M., Aber, J., Howarth, R.W., Likens, G.E., Matson, P.A., Schindler, D.W., Schlesinger, W.H., Tilman, D., 1997. Human alteration of the global nitrogen cycle: causes and consequences. Issues in Ecology 1, 1-16.

Watt, P.J., Oldham, R.S., 1995. The effect of ammonium nitrate on the feeding and development of larvae of the smooth newt, Triturus vulgaris (L.), and on the behaviour of its food source, Daphnia. Freshwater Biology 33, 319-324.

Wright, P., Anderson, P., Weng, L., Frick, N., Wong, W.P., Ip, Y.K., 2004. The crabeating frog, Rana cancrivora, up-regulates hepatic carbamoyl phosphate synthetase I activity and tissue osmolyte levels in response to increased salinity. Journal of Experimental Zoology 301A, 559-568.

Xu, Q., Oldham, R.S., 1997. Lethal and sublethal effects of nitrogen fertilizer ammonium nitrate on common toad (Bufo bufo) tadpoles. Archives of Environmental Contamination and Toxicology 32, 298-303. 